\title{
URBAN CONFLICTS IN TIMES OF DIGITAL AGE
}

\author{
Artem MOZGOVYI \\ Institute of Geography, National Academy of Science of Ukraine, Kyiv, Ukraine \\ utor@ukr.net
}

\begin{abstract}
The article is devoted to the geographical study of conflict in urban space in times of digital age. The information age brings new challenges but opens new opportunities for geographic research of urban conflicts. The methods and techniques that can be used in geographic studies of urban conflicts are considered. However, the geographical study of conflicts requires broader involvement of the methods from related branches of knowledge and other sciences. The city is considered as a complex territorial system. Scientific content of the concepts of "space", "geographical space", "urban space" is defined and differentiated. In the process of studying of urban conflict we also demarcated such concepts as "conflict situation", "frequency of conflicts" and "risk of conflicts". The main approaches to the systematization of urban conflicts were summarized. The theory and practice point out that conflicts seem to be a prerequisite for urban development. It has been found that digital technologies can be most effective in preventing and solving "people - machine" or "machine - machine" conflicts; at the same time, solving social conflicts among different stakeholders and directing their devastating potential to a constructive path requires social communication between the conflicting parties and the application of integrated urban development approach.
\end{abstract}

Key words: conflict, city, urban space, digital age, conflict activity, conflict potential.

DOI: https://doi.org/10.17721/2413-7154/2017.78.18-25

UDC: 911.375 .3

\section{МІСЬКІ КОНФЛІКТИ В ІНФОРМАЦІЙНУ ЕРУ}

\author{
Артем Мозговий \\ Інститут географії НАН України, м. Київ, Україна \\ utor@ukr.net
}

\begin{abstract}
Анотація: Висвітлено географічні аспекти конфліктності міського простору як складної відкритої суспільнотериторіальної системи в інформаційну еру. Установлено, що інформаційна ера розвитку суспільства несе як виклики, так і відкриває нові можливості для географічних досліджень міських конфліктів. Розглянуто методи та прийоми, які можуть знайти застосування у географічних дослідженнях міських конфліктів. Проте, географічне дослідження конфліктів потребує широкого залучення методів суміжних галузей знань та інших наук. Простежено понятійно-ієрархічний ряд: «простір»- «географічний простір»- «міський простір». Схарактеризовано конфліктну взаємодію в міському просторі. Також було розмежовано такі поняття як «конфліктна ситуація», «конфліктність» і «конфліктогенність». Узагальнено основні підходи до систематизації міських конфліктів. Визначено, що конфлікти $\epsilon$ не тільки наслідком динамічного міського розвитку, але і необхідною його умовою. 3'ясовано, що цифрові технології можуть бути найбільш ефективними при упередженні та розв'язанні ергатичних конфліктів в міському середовищі. Водночас, розв'язання соціальних конфліктів між носіями різних інтересів та спрямування їхнього руйнівного потенціалу до конструктивного русла потребує соціальної комунікації між сторонами конфлікту та застосування методів інтегрованого міського розвитку.
\end{abstract}

Ключові слова: конфлікт, місто, міський простір, інформаційна ера, конфліктність, конфліктогенність.

DOI: https://doi.org/10.17721/2413-7154/2017.78.18-25

UDC: 911.375 .3

Вступ. Постановка проблеми. Прихід інформаційної ери на зміну індустріальній добі має тектонічні наслідки для соціальної організації, культури та економіки сучасного суспільства. Висліди мислителів щодо цих цивілізаційних зрушень викладено в безлічі філософських,

(C) А. Мозговий культурологічних, соціологічних, економічних праць. Переважно вони присвячені визначенню місця людини, ㄲï суб'єктності та різним аспектам людської діяльності в постіндустріальному світі. Хоча перехід від індустріальної до інформаційної ери в літературі часто іменують «цифровою революцією», на нашу думку, це явище не в повній мірі відповідає такому поняттю як «наукова 
революція», зокрема за Томасом Куном (Thomas Kuhn): «революція як зміна світогляду» [2]. Радше ми маємо справу 3 діалектичним кількісноякісним переходом: від винайдення персональних комп'ютерів наприкінці 1970-х рр. і до створення їхньої глобальної мережі на початку 1990-х рр., коли кожен представник суспільства отримав можливість необмеженого доступу до всього накопиченого досвіду людства. Це безпрецедентний крок людства до вільного пересування інформаційним простором.

Під впливом цифрової доби все частіше дослідження міського середовища пов'язані 3 тематикою т.зв. «гібридного урбанізму», тобто дослідженням того, яким чином цифрові технології знаходять прояв в міському просторі, яке застосування вони можуть мати та які зміни міського середовища можуть спровокувати. У сучасному світі особисті дані стають новим економічним ресурсом, що порушує проблему захисту прав власності на них та збереження приватності. Уже нині таке відкрите програмне забезпечення для фільтрації змісту та блокування реклами як адблоки істотно впливає на структуру споживання товарів та послуг містянами. Найближчим часом високотехнологічні продукти доповненої реальності неминуче почнуть проникати в фізичний простір міста, що породить нову проблему регулювання та законодавчого унормування цієї «цифрової експансії». Скоро міські поверхні (стіни, тротуари, проїзна частина автошляхів та ін.) заповнять сенсори, інтерфейси і голографічні зображення, що має істотно вплинути на моделі поведінки містян. Також інформаційна ера породила проблему співвідношення масової культури і міських субкультур, утворення замкнених соціальних спільнот та проблему насильства як основного засобу самовираження, що значно підвищує конфліктогенність міського середовища.

Ми окреслили тільки окремі проблеми, що вже виникли, або можуть виникнути в осяжному майбутньому під впливом розвитку технологій. Усі ці виклики потребують відповідей з боку науки. Географія, на нашу думку, має весь необхідний методичний апарат для пошуку відповідей на згадані вище складні питання.

Аналіз останніх досліджень і публікацій. Міждисциплінарні дослідження міських конфліктів $\epsilon$ нині доволі популярним напрямом в світовій науці. 3 останніх досліджень міських конфліктів хотілося б зупинити увагу на книзі іспанського географа Луїса дель Ромеро (Luis del Romero) «Конфлікти в місті: роздуми про міські заворушення» [13]. Учений стверджує, що міжнародна фінансова криза, що розпочалася майже десятиліття тому, є своєрідним одиночним виявом більш глибинних процесів: поступового демонтажу «держави добробуту», деградації житлових умов у місті, піднесення міських гетто у європейських містах тощо. Досліджуючи міста країн південної Свропи, дослідник виявив два провідні соціальні та політичні тренди, що мають істотне значення для сьогодення: по-перше, молоді покоління південноєвропейців мають усе гірші умови життя, ніж їхні батьки; по-друге, неспроможність біномічної політичної демократії капіталізму. Соціальна напруга, що викликана цими чинниками, може призвести, на думку автора, до призупинення регулярних демократичних механізмів в таких країнах як Португалія та Греція. У цьому контексті міський конфлікт стає центром політичних, академічних та публічних дебатів. Відмінність сучасних міських протестів полягає в тому, що вони більше не зосереджені на трудових проблемах, як це традиційно траплялося, а все частіше мають причини в сфері соціального відтворення: житло, громадський простір, освіта, охорона здоров'я або проблеми навколишнього середовища. Автор приділяє всебічну увагу розумінню конфлікту як соціального явища, аналізу генези, еволюції та вирішенню конфліктів шляхом знаходження консенсусу серед широкого кола учасників конфліктів. Учений пропонує розглядати міський конфлікт як необхідний і єдино можливий сценарій спілкування між міськими акторами в ситуації, коли комунікації бракує. Книга «Конфлікти в місті: роздуми про міські заворушення» присвячена причинам виникнення міських конфліктів та їхнього головного прояву масовим протестам.

У контексті тематики нашої публікації цікавою є також книга «Технологія та майбутнє міст: можливості та рекомендації» за редакцією Дайани Вашингтон (Diana Washington) [16]. У книзі констатується, що міста вступають в епоху значних перемін. Автори простежують новітню тенденцію в розвитку американських міст - від 2011 р. до ядер агломерацій почало повертатися населення, створюючи нові соціальні зв'язки та зручність в центральних міських кварталах. Окрім проблем, що супроводжують відродження житлових кварталів центральної частини міст, $є$ й більш складні, на думку авторів, проблеми, що охоплюють питання сталого міського розвитку, стійкості міст до змін клімату та стихійних лих. Ця книга зосереджена на висвітленні технологій, які формують інформаційну інфраструктуру сучасного міста та цифрову економічну діяльність. Автори також окреслюють нове бачення і узагальнюють підходи в організації розумних міст та інтегрованих міських спільнот.

Також заслуговує на увагу з боку географів і нова книга професора Торонтського університету Річарда Флориди (Richard Florida) «Нова міська криза» [10]. У останні два десятиріччя освічена і творча молодь почала активно повертатися 3 приміської зони до великих міст. Флорида - один 3 перших вчених, що передбачили цей зворотний рух від субурбії до міст в своєму масштабному дослідженні «Зростання творчого класу» [9]. Автор демонструє на численних прикладах, як ті ж самі сили, що сприяють піднесенню креативного класу, у той же час створюють складні проблеми: соціальна недоступність, сегрегація та майнова нерівність. Тим часом, багато інших міст все 
ще залишаються стагнатами, а спільноти середнього класу - основа американського суспільства повсюдно зникають. І це лише один з проявів глибокої кризи в сучасній урбанізованій економіці знань. Праця містить докладний опис економічних негараздів, що супроводжують сучасні американські міста, та пропонує шляхи створення більш інклюзивних міст, здатних забезпечити зростання та процвітання для всіх груп містян.

Формулювання цілей статті. Постановка завдання. Мета цієї наукової розвідки полягає у розкритті природи конфліктів, що виникли в міському просторі в добу цифрових технологій та оцінити нові можливості географічної науки для їх наукового дослідження.

Виклад основного матеріалу. Уже нині технології відкривають нам можливості для здійснення масштабних і точкових втручань до багатьох областей міського життя. Наприклад, вже буденними стали аналіз моделей міського транспортного трафіку, ефективне зонування міського простору та створення міських спільнот за найрізноманітнішими ознаками. У той самий час, важливо усвідомити, що повсюдне застосування інтернет-технологій породжує потребу в «цифровому мисленні», що передбачатиме аналіз значних баз даних в режимі реального часу та відкриє шлях до створення високоадаптивних міських інформаційних систем, котрі практично миттєво підлаштовуватимуться під запити конкретних користувачів. Уже сьогодні прикладом такого «цифрового мислення» може слугувати сервіс міського пересування Uber, або ж проекти компанії Pavegen - провідного розробника нового типу вуличного освітлення, що працює від сонячної енергії та кінетичної енергії перехожих.

Оскільки цифрові технології все глибше проникають в буденне життя містян, утворюючи в їхньому побуті постійно діючу мережу пристроїв, що іноді називають «інтернетом речей», кожна людина виробляє приголомшливий обсяг даних, які об'єднуються в одне ціле 3 планетарними даними всього людства. Ерік Шмідт (Eric Schmidt), людина, що є одним з найпомітніших провідників інформаційної ери, під час своєї роботи в Google відзначав, що кожні дві доби людство створює стільки ж інформації, скільки було створено 3 моменту зародження цивілізації до 2003 року, тобто майже п'ять ексабайт даних (один ексабайт - це квінтильйон, тобто $10^{18}$ байтів) [7]. Крім того, в міру того, як відбувається подальший збір i зберігання цифрової інформації, «роздільна здатність» віртуальної копії нашого світу стає все більш високою. Так, наприклад, автомобілі компанії Google їзили різними країнами світу, роблячи панорамні зйомки місцевості. Після п'яти років роботи команда, що займалася панорамними зйомками для Google Maps, повідомила, що за цей час їхні автомобілі відобразили п'ять мільйонів миль доріг в тридцяти дев'яти країнах неймовірним загальним обсягом в двадцять петабайт даних, що приблизно дорівнює кільком квадрильйонам зображень. Очевидно, що переважна більшість цих зображень асоційована з міськими просторами.

Географія, як «наука про місця» в інформаційну еру, отримує окрім загроз, пов'язаних 3 явищем «стиснення простору», також і значні дослідницькі переваги. Ці переваги пов'язані в першу чергу 3 тим, що будь-який масив просторових даних, зібраний для певної мети, має значне число пов'язаних 3 цими даними потенційних побічних результатів. Дослідники, що працюють 3 потоком міської інформації, часто називають цю особливість опортуністичним сприйняттям (opportunistic sensing): використання даних, що були згенеровані 3 однією метою для досягнення іншої мети - аналізу в іншому контексті для отримання нових наукових результатів [11]. Масиви даних часто мають багато вимірів, і незалежно від того, чи передбачалося використання кожного 3 цих вимірів в момент створення, кожен аспект цих даних згодом може бути інструменталізований несподіваним і творчим чином. Наприклад, дані транзакцій з використанням кредитних карток мають унікальні ідентифікаційні коди для продавця і для покупця. Ці коди дозволяють дослідникам фільтрувати дані за місцем і типом покупки (продукти харчування, одяг, паливо, послуги та ін.) для визначення патернів (закономірної регулярності) економічної поведінки містян [15].

Аналіз телекомунікаційних даних і соціальних медіа показав, що і те і інше є потужним інструментом для розуміння функціонування соціальних зв'язків i механізмів їх розвитку. Масиви даних можна розглядати індивідуально, але набагато краще уявлення можна отримати при накладенні їх один на одного, а також при аналізі місць їх перетинів. Спільним знаменником, що дозволяє нам зіставляти їх один з одним, є географічний простір. Особливо зараз, коли можна з'єднувати i переплітати між собою різні потоки інформації, міські дані можуть дати нам як ніколи раніше ясну картину життя. Ще 3 середини 2000-х рр. дослідники почали пов'язувати дані про використання мобільного зв'язку з даними про переміщення населення. Трохи пізніше були зроблені вдалі спроби візуалізації подібної інформації, як, наприклад, під час такої виняткової події як фінальний матч Чемпіонату світу з футболу в Римі 2006 р., дозволив побачити, на скільки колективна поведінка людей була безпосередньо пов'язана 3 цією подією. Перед початком гри рух i використання мобільного зв'язку завмерли, під час матчу активність майже припинилася, в перерві різко зросла, впала майже до нуля під час напружених останніх хвилин і вибухнула після закінчення матчу. У наступні кілька годин по слідах мобільного зв'язку можна було спостерігати масовий рух в центр міста для святкування перемоги національної команди [8]. У інших проектах в містах, де доступ до даних організовано простіше, як, наприклад, в Сінгапурі, масиви даних були ще більшими. Дані про погоду, про поштові відправлення, про використання громадського транспорту, стільникових мереж і інші з'єдналися в єдиний потік, щоб створити багатомірний образ певного міста. 
Крім опортуністичного сприйняття, дані можна генерувати за допомогою сенсорів певного призначення. При впровадженні технологій в міське середовище можна отримувати надійні і докладні дані, які потім можна використовувати, наприклад, для складання карти будь-якої системи, для виявлення прихованих процесів або для отримання нового розуміння звичних процесів. Наведемо як приклад систему утилізації сміття.

У міру того як все більше і більше таких електронних елементів впроваджується в фізичний простір, можна виявити багато інших аспектів міського середовища. Senseable City Lab запустила проект «Відстеження сміття», який звертався до сценарію повсюдного трекінгу. Дослідникирозробили геолокаційні мітки і за допомогою жителів Сіетла приєднали їх до тисяч одиниць звичайного сміття, створивши «інтернет сміття», щоб відстежити ланцюжок утилізації відходів на території США [12]. Протягом наступних місяців за допомогою міток вдалося виявити дивовижну мережу, про існування якої ніхто раніше не здогадувався. У найближчому майбутньому, з прискоренням поширення технологій в міському просторі, можна буде отримати безпрецедентне розуміння функціонування подібних систем, а також створити дані, які можна буде використовувати для оптимізації всієї системи, навіть в реальному часі.

Описані вище методи та прийоми можуть знайти широке застосування в географічних дослідженнях міського середовища, зокрема у дослідженнях міських конфліктів. На нашу думку, найбільш ефективними 3 вищеперелічених можуть стати методи дослідження міських конфліктів засобом аналізу телекомунікаційних даних і соціальних медіа. Особливо, якщо йдеться про тривалі й затяжні соціальні конфлікти, що розгортаються в міському просторі, наприклад, тривалі масові протести громадян. Після етапу «камерального» визначення предмета й об'єкта конфлікту, конфліктогенів та інцидентів, аналіз телекомунікаційних даних i соціальних медіа дозволив би визначити територіальні та часові межі конфлікту, відстежити динаміку конфлікту, кількісні характеристики його основних стадій та етапів. Припускаємо, що аналіз телекомунікаційних даних і соціальних медіа дозволив би науковцям зробити певні висновки навіть щодо суб'єктної структури конфліктів, визначити, наприклад, ядра колективних сторін конфлікту, поля обсервації (спостереження) та медіації (посередництва). Проте за умов доволі обмеженого доступу науковців до телекомунікаційних даних операторів стільникового зв'язку в Україні потенціал подібних досліджень поки що лишається майже нереалізованим. Сподіваємось, що 3 ухваленням українським парламентом прогресивного законодавства в галузі електронних довірчих послуг та ідентифікації громадян за допомогою електронного цифрового підпису, а також відкриттям можливостей для впровадження в нашій країні сервісу MobileID, неперсоніфіковані телекомунікаційні дані стануть більш доступними для дослідників.

За дослідницьких умов, що склалися, зробимо короткий огляд класичних географічних методів, що можуть бути застосовані при дослідженні конфліктної взаємодії на конкретній території. Так, доволі ефективними виявляються спеціальногеографічні методи: описово-географічний, порівняльно-географічний та історикогеографічний. Зумовлено це тим, що, по-перше, конфлікт як явище в сучасній науці має вже усталену схему опису, котру видається можливим адаптувати до потреб географії. По-друге, акумульована база описів конфліктів на конкретній території створює широке поле для компаративістики. Стають можливими не тільки порівняння конфліктів, що відбуваються в межах різних територіальних систем, а порівняння різночасових конфліктів.

Використання методу районування при дослідженні конфліктів матиме певні особливості, так як при дослідженні конфліктів використання категорій спеціалізації території, наявності центру, а також виділення меж районів матиме, на нашу думку, методологічні обмеження. Більш прийнятним для потреб географічного дослідження конфліктів нам видається зонування території за кількісними і якісними характеристиками конфліктів.

Також можемо виснувати, що картографічний метод дослідження конфліктної взаємодії на території дозволяє відобразити: ареали поширення конфліктів різного типу на певній території, ступінь конфліктності, динаміку перебігу того чи іншого конфлікту. У цьому контексті, особливо цінним для нас $є$ досвід історичної науки, а саме - створення історичних карт конфліктів.

Проте необхідно враховувати, що при безоглядному використанні географічних методів в дослідженнях конфліктів створюється загроза редукціонізму. Спрощений погляд на конфлікт як систему може загрожувати науковою некоректністю отриманих результатів. На нашу думку, географічне дослідження конфліктів потребує широкого залучення методів суміжних галузей знань та інших наук. За умов відсутності в національній статистичній системі даних, що безпосередньо, або ж опосередковано характеризували б конфліктність в населених пунктах та за їх межами, збір даних для потреб дослідження, на нашу думку, має грунтуватись на івент- та контент-аналізі, системноситуативному аналізу та групі інших соціологічних методів дослідження конфліктної взаємодії.

Окремою урбаністичною проблемою сучасності $є$ питання організації та функціонування «розумного міста». Можна стверджувати, що «розумне місто» (Smart City) - урбаністична мрія інформаційної ери. Місто, що знаходиться під контролем технологій, де проблеми вирішуються в режимі реального часу завдяки алгоритмам миттєвої передачі даних i наданню відповідних рішень. У такому місті інженер стає до шерегу міських професій нарівні з урбаністом та архітектором. Складність розумних міських систем вимагає поглиблених міждисциплінарних 
досліджень і розробки інтегрованого міського управління, заснованого на розумінні як фізичного міського простору, так і віртуального.

Сучасне зближення цифрових технологій та архітектури породило нову діалектику, яка впливає на міський простір, де першорядну роль відіграють проблеми технічного контролю, доступу і свободи дій. Хоча пізніше поява комп'ютерних мереж зробила можливим створення середовища, підлаштованого під потреби користувача, воно ж породило i витончені форми централізованого контролю над міським простором і соціальною взаємодією. Цифрові мережі надають нам можливість «газоподібного розсіювання» міських структур, але іншою стороною цієї медалі є посилення контролю за пересуванням, діями i контактами людей, накопиченням відомостей про них в електронних базах даних. Усе частіше можна почути насторожені оцінки 3 боку експертного середовища урбаністів щодо можливої загрози для демократії з боку високотехнологічного міського середовища.

Таким чином, розвиток міського простору в інформаційну еру охоплює широке коло теоретичних і прикладних питань, дослідження котрих грунтується на таких концептах та базових наукових категоріях як «система», «розвиток» та «простір». Географічний зміст кожного 3 них виповнений множиною понять, термінів та причинно-наслідкових зв'язків. Географічні об'єкти як територіальні системи мають неабиякий потенціал розкриття змісту цих базових наукових категорій. Яскравим прикладом таких територіальних систем є місто.

У нашому дослідженні ми використовуємо наступний понятійно-ієрархічний ряд: «простір»«географічний простір» - «міський простір». Отже, географічний простір (геопростір) ми розглядаємо як підпростір фізичного простору. У сучасній українській географічній науці під геопростором розуміють «множину географічних об’єктів, які мають своє місцеположення, та множину відношень між ними» [5]. Принагідно зауважимо, що у науковому вжитку вже доволі тривалий час використовується поняття «цифровий міський простір» [14], хоча цей термін має доволі вузьке значення і використовується переважно фахівцями з 3D-картографування.

Виходячи 3 того, що «територіальність, прив'язка до території $€$ прямою ознакою географічних досліджень i географічних об'єктів, суміщення і накладання різних видів простору очевидне» [6], міський простір ми розглядаємо як складову географічного простору. Як природно-територіальні, так і суспільнотериторіальні системи не можливі поза «місцем». Територіальність є однією з найважливіших ознак подібних утворень. Хоча сучасні міста переважно лишаються, радше, дискретною формою територіальної організації суспільства, однак вони теж складаються 3 окремих територіальних частин (підсистем), а також $є$ територіальними складовими масштабніших географічних об'єктів. Елементам суспільно-територіальної системи міста притаманні такі територіальні параметри, як різний ступінь доступності, територіальна конфігурація, територіальна концентрація тощо. Вочевидь, згадані територіальні параметри істотно впливають на розвиток конкретного міського поселення.

Питання просторового розвитку, в тому числі й міського, що грунтується на принципах «збалансованого просторового розвитку», знайшли своє відображення в основній парадигмі XXI століття - сталого збалансованого економічного, соціального та екологічного розвитку. Дослідження проблем сталого розвитку населених пунктів, особливо міст, є нині одним із стрижневих напрямів наукового обгрунтування планетарної концепції сталого розвитку.

3 одного боку, стійкість розвитку населених пунктів часто виступає однією 3 провідних тем при обговоренні в наукових колах можливостей глобального переходу сучасної цивілізації до моделі сталого розвитку. Сьогодні не уявляється можливим ведення професійної дискусії 3 проблематики сталого розвитку без участі фахівців-урбаністів. Концепція сталого розвитку населених пунктів розвинулася в самостійну галузь, як теоретичної, так і прикладної спрямованості, що сприймається нині науковою громадськістю як природна і невід'ємна частина парадигми сталого економічного, соціального та екологічного розвитку нашої планети.

Принагідно зауважимо, що у проекті «Стратегії сталого розвитку України до 2030 року» серед операційних цілей чітко визначено «зробити міста та населені пункти інклюзивними, безпечними, життєстійкими та збалансованими» [4]. Значна частина визначених в проекті стратегії завдань перегукується 3 принципами організації «розумного міста». Зокрема ті завдання, що стосуються впровадження екологічно збалансованих транспортних систем, систем інтегрованого поводження 3 відходами, функціонування систем раннього оповіщення населення про природні та техногенні загрози тощо.

Конфліктуючими сторонами в міській системі можуть виступати суб'єкти господарської діяльності, органи управління, суспільні групи, окремі особи і навіть технічні системи. Як зазначалось вище, міські конфлікти найчастіше виникають як результат загострення суперечностей розвитку міської системи. Конфліктувати між собою можуть навіть різні види розвитку міста, тобто територіальний, демографічний, функціональний та соціально-економічний розвиток. До конфліктної ситуації також може призводити конкуренція між суб'єктами. Одначе, на нашу думку, не слід ототожнювати конкуренцію 3 конфліктом, так як сама по собі змагальність між суб'єктами за покращення умов функціонування в межах міського простору, за ресурси розвитку, чи досягнення певного стану дійсності не обов'язково призводить до конфлікту. Основними відмінними рисами конкуренції та 
конфлікту є те, що за конкуренції суб’єкти діють кожен «на своєму полі», а також те, що дії задля забезпечення успіху мають позитивний характер. Цікавим аспектом цього питання $є$ конкуренція між містами як економічними системами, або ж образами та брендами міст. Ця проблематика потребує окремого дослідження.

При характеристиці конфліктної взаємодії в міському просторі важливим $є$ розрізнення таких понять як конфліктна ситуація, конфліктність та конфліктогенність. Зупинимось на них більш ретельно.

Конфліктна ситуація - це збіг обставин, чи умов, що об'єктивно містить явні передумови для конфлікту i провокує деструктивні дії сторін, тобто виникнення конфлікту. Конфліктна ситуація $\epsilon$ передумовою реального конфлікту. Часто-густо iii асоціюють 3 власне конфліктом, що $є$ хибним уявленням, так як конфлікт може мати неявну, приховану, латентну фазу. Вона $є$ неявною для стороннього спостерігача, тому може лишитись непоміченою. Конфліктна ситуація в міському просторі сигналізує про нагальну необхідність втручання з боку муніципалітету. Конфліктам між приватними і громадськими інтересами містян, між різними міськими підсистемами завжди передує конфліктна ситуація. Розв'язання конфліктних ситуацій - показник ефективності міської влади.

У свою чергу, конфліктність - це показник, що характеризує частоту і гостроту виникнення i перебігу конфліктів в місті, ступінь залученості до конфліктної взаємодії суб'єктів. Виділяють низьку, середню, оптимальну i високу конфліктність. Центральною детермінантою конфліктності $є$ система суперечностей, що виникають в процесі міського розвитку i відтворення предметного плану соціально-економічної активності. Рівень емерджентності в розвитку міста як системи, ступінь ефективності спільної діяльності суб'єктів міського середовища виступає провідним фактором, що визначає змістовні причини та інтенсивність конфліктності в місті. На прикладі дослідження інших складних систем конфліктологами було помічено, що деякий рівень конфліктності не $є$ фактором дезінтеграції високоефективної системи спільної діяльності. Такий рівень конфліктності $є$ оптимальним для функціонування системи.

Враховуючи вищевикладене, на цьому етапі дослідження, під конфліктогенністю міського розвитку ми пропонуємо розуміти потенціал можливих конфліктів, що виникатимуть в процесі взаємодії суб'єктів міського розвитку, що може впливати на стан міського середовища та проявляється у мобілізації просторових, матеріальних і нематеріальних ресурсів, асиметричності деструктивних дій, та може призвести до згубних наслідків для сторін-носіїв інтересів. Конфліктогенність характеризує потенціал конфліктної взаємодії на території: міста в цілому, окремого району, зони впливу міста.

Трансформація індустріального міського ландшафту почалося ще на початку XX століття, однак в другій половині століття подібні перетворення істотно посилились. Реструктуризація економіки відбувалася вже не в національному масштабі, а була поширеною в багатьох країнах. Крім того, часові відтинки, за яких інновації встигали застаріти, ставали дедалі коротшими, що формувало типове для сучасності уявлення про циклічність змін, наприклад, в моді, а також притуплення у містянина відчуття новизни. Довговічність міських форм, що раніше вважалась чимось само собою зрозумілим, перейшла в категорію неприродного. Показово, що протягом всього XX століття архітектори-авангардисти мріяли про «рухоме місто», що складалося 3 «портативних» структур і «мобільних будинків». Інший підхід був сформульований в 1920-х рp. конструктивістами, зокрема архітектурною школою Баухауз. Його суть полягала у використанні нових матеріалів і методів дизайну для створення багатофункціональних просторів. До початку 1960-х рр. створення «гнучкого» міського середовища все більше розглядалося як злиття модерністських принципів багатофункціонального дизайну 3 новими медіа та комп'ютерною технікою [3].

Обидва ці явища: і «заміна людей цифрами», яку Фрідріх Киттлер (Friedrich Kittler) вважав головним результатом дії сучасних медіа [1], i регуляризація міського простору, надання йому контрольованих форм, надзвичайно зросли за рахунок комп'ютеризації культури. Перетворення «статистичного суспільства» XIX століття в «кібернетичне» суспільство XX століття докорінно змінило взаємозв'язок між інформацією та матерією. Цифровий простір міста 3 його пріоритетом мобільності в сучасному суспільстві, може відображати не тільки нову соціальну свободу, але і всеосяжність механізмів контролю. Характерний для цифрових технологій зворотний зв'язок легко обертається функціональною тотальністю, що перевершує споконвічну ідею міської єдності.

Окремою проблемою в дослідженні конфліктів в міському просторі є питання про їх систематику. У сучасній науковій практиці систематизації конфліктів існує безліч підходів. Це обумовлено досить широким колом наук і галузей знань, які вивчають конфлікти - від психології до теорії міжнародних відносин. Проаналізувавши i порівнявши існуючі класифікації конфліктів, запропоновані представниками різних наук, ми прийшли до висновку, що для потреб географічного дослідження конфліктів можуть бути використані далеко не всі $з$ них.

При систематизації конфліктів міського простору дедуктивним шляхом дослідник отримує можливість оперувати конкретними просторовочасовими таксонами (класами) конфліктів. 3 нашого досвіду, різні класифікації конфліктів більш ефективно застосовувати на перших польових етапах дослідження. I навпаки, на більш пізніх етапах, рухаючись індуктивним шляхом, дослідник відкриває можливість більш ефективного 
застосування таксонів якісного характеру (типів) конфліктів міського простору.

Процес систематизації конфліктів передбачає глибокий підхід до ідентифікації об'єкта і суб'єктів, передумов i наслідків конкретного конфлікту, що розвивається в міському просторі. Тому при дослідженні міських конфліктів незамінною стає тріада класичних методів: описово-географічного, історико-географічного та порівняльно географічного. «Паспортизація» міських конфліктів, проведена за допомогою вищезазначених методів, дозволяє географу досить чітко визначити масштаби впливу того, чи іншого конфлікту на міський розвиток. Тобто географічна «прив'язка» загальнонаукової типізації конфліктів, на нашу думку, створює нові дослідницькі можливості. Найбільш яскраво проілюструвати це можна на прикладі дослідження ергатичних конфліктів, тобто конфліктів різних міських підсистем, де суб'єктність в традиційному уявленні як така відсутня. Саме географія має широкий інструментарій для таких досліджень, чого не скажеш, наприклад, про науки суспільногуманітарного циклу.

Неоціненною є роль географії і при дослідженні екологічних конфліктів в міському просторі. Саме міста $є$ головними центрами локалізації протиріч між людством і природним середовищем. В першу чергу це стосується промислових центрів, вузлів i агломерацій, приурочених до великих міст.

Згадавши про екологічні конфлікти в міському просторі зауважимо, що місто споживає для свого розвитку ресурси, які створюються на величезних просторах природних комплексів, що мають площу незрівнянно більшу, в порівнянні 3 містом. I при цьому саме в містах продукується основна частина токсичних промислових відходів та побутового сміття. Загальновідомо, що в містах продукується близько $80 \%$ загальносвітових викидів вуглекислого газу, що $\epsilon$ головним чинником виникнення парникового ефекту. Масу відходів не в змозі асимілювати міське середовище, оскільки його екологічна ємність незрівнянно менше антропогенних навантажень, тому техногенна напруга в містах постійно зростає.
Висновки і перспективи подалыших розвідок. У результаті цієї короткої наукової розвідки можемо зробити наступні висновки і узагальнення:

Установлено, що інформаційна ера розвитку суспільства несе як виклики, так і відкриває нові можливості для географічних досліджень. Проблема «стиснення простору» і нівелювання величезних відстаней при передачі фактично необмежених обсягів інформації викликають певну ревізію традиційних географічних уявлень про простір, місцеположення та місце. Водночас цифрова доба відкриває можливості для застосування в географічних дослідженнях нових методів та прийомів, наприклад, просторового аналізу телекомунікаційних даних, що сприяє розвитку географічної науки.

Узагальнено новітні тенденції в розвитку міського простору i доведено, що зближення цифрових технологій та архітектури породило нову реальність, що безпосередньо впливає на міський простір, де першорядну роль відіграють проблеми технічного контролю, доступу і свободи дій. Цифрові мережі надають нам можливість ефективної інтегрованої роботи міських структур, але 3 іншого боку сприяють посиленню контролю за пересуванням, діями i контактами містян, накопиченням відомостей про них в електронних базах даних, що, на думку багатьох урбаністів, створює певні загрози для міської демократії з боку високотехнологічного міського середовища.

3'ясовано, що цифрові технології можуть бути найбільш ефективними при упередженні та розв'язанні ергатичних конфліктів в міському середовищі, коли конфліктна ситуація створюється на рівнях «людина-машина» та «машина-машина». Підвищення рівня регульованості інфраструктурою та міськими процесами, наприклад, транспортним рухом, до певної межі буде сприяти уникненню ергатичних конфліктів. Водночас, розв'язання соціальних конфліктів між носіями різних інтересів та спрямування їхнього руйнівного потенціалу до конструктивного русла потребує соціальної комунікації між сторонами конфлікту та застосування методів інтегрованого міського розвитку.

\section{References:}

1. Kittler A. Friedrich. Mir simvoličeskogo - mir mašiny [The world of the symbolic - a world of the machine]. [Electronic source]. Access mode: http://www.intelros.ru/pdf/logos/1_2010/2.pdf

2. Kuhn T. The structure of scientific revolution. University of Chicago Press, 1962, $172 \mathrm{p}$.

3. Scott McQuire. The Media City: Media, Architecture and Urban Space. London: Sage Publications, 2010, 228 pp.

4. Strategiâ stalogo rozvitku Ukraïni do 2030 roku. Proekt-2017 [Strategy for Ukraine's Sustainable Development until 2030. Project - 2017]. Kyiv, 2017, 110 p. (In Ukrainian).

5. Topčiêv O.G. Suspil 'no-geografičnì doslidžennâ: metodologîa, metodi, metodiki [Research in human geography: methodology, techniques, approaches]. Odessa: Astroprint, 2005, 632 p. (In Ukrainian).

6. Ukraïna: osnovni tendenciï vzaêmodï suspil'stva i prirodi u XX st. (geografičnij aspekt) [Ukraine: the main tendencies of the interaction of society and nature in the XX century (geographic aspect)]. (Ed. Rudenko L.G.) Kyiv, National Academy of Science of Ukraine, Institute of Geography, Akademperiodyka, 2005, 320 p. (In Ukrainian). 
7. Smidt E., Jared K. The new digital age: Transforming Nations, Businesses, and Our Lives. New York: Vintage Books, 2014, $351 \mathrm{p}$.

8. Calabrese F., Massimo C., Piero L., Dario P., Carlo R. Real-time urban Monitoring using cell phones: a case study in Rome. IEEE Transactions on Intelligent Transportation Systems, 2011, No. 1, pp.141-151. [Electronic source]. Access mode: http://dx.doi.org/10.1109/TITS.2010.2074196

9. Florida R. The rise of the creative class. New York: Basic Books, 2014, $509 \mathrm{p}$.

10. Florida R. The new urban crisis: how our cities are increasing inequality, deepening segregation, and failing the middle class and what we can do about it. New York: Basic Books, 2017, $310 \mathrm{p}$.

11. Phithakkitnukoon S., Wolf M. I., Offenhuber D., Lee D., Biderman A., Ratti C. Tracking trash. IEEE Pervasive Computing, 2013, No. 12(2), pp. 38-48. [Electronic source]. Access mode: http://oro.open. ac.uk/35876/108/TT.pdf

12. Ratti C., Claudel M. The city of tomorrow: sensors, networks, hackers, and the future of urban life. New Haven, CT: Yale University Press, 2016, 192 p.

13. Romero Renau Luis del. Conflicts in the city: reflections on urban unrest. Hauppauge, NY: Nova Science Publishers, 2015, $210 \mathrm{p}$.

14. Shibasaki R., Nakamura H. A digital urban space model for urban planning and management. Applications of Geodesy to Engineering. International Association of Geodesy Symposia. Linkwitz K., Eisele V., Mönicke H.J. (eds). Berlin-Heidelberg: Springer, 1993, Vol. 108. [Electronic source]. Access mode: https://doi.org/10.1007/978-3642-77958-9_22

15. Sobolevsky S., Sitko I., Combes R. T., Hawelka B., Murillo A. J., Ratti C. Money on the move: big data of bank card transactions as the new proxy for human mobility patterns and regional delineation. The case of residents and foreign visitors in Spain. IEEE International Congress on Big Data (BigData Congress), 2014, pp. 136-143. [Electronic source]. Access mode: https://github.com/bbvadata/bbvadata_papers

16. Technology and the future of cities: opportunities and recommendations (Ed. Diana L. Washington). Hauppauge, NY: Nova Science Publishers, 2016, 164 p. 